\title{
Clinical Trial Site Personnel Contact Document
}

National Cancer Institute

\section{Source}

National Cancer Institute. Clinical Trial Site Personnel Contact Document. NCI Thesaurus.

Code C115671.

Records that contains the contact information for members of the clinical trial team. 